Supporting Information

\title{
Degradable Redox-Responsive Polyolefins
}

Christina M. Geiselhart, ${ }^{a, b}$ Wenwen Xue, ${ }^{a, c}$ Christopher Barner-Kowollik*b,d,e and Hatice Mutlu*a

aSoft Matter Synthesis Laboratory, Institut für Biologische Grenzflächen, Karlsruhe Institute of Technology (KIT), Hermann-von-Helmholtz-Platz 1, 76344, Eggenstein-Leopoldshafen, Germany.

${ }^{b}$ Macromolecular Architectures, Institut für Technische Chemie und Polymerchemie, Karlsruhe Institute of Technology (KIT), Engesserstraße 18, 76128, Karlsruhe, Germany.

'Preparative Macromolecular Chemistry, Institut für Technische Chemie und Polymerchemie, Karlsruhe Institute of Technology (KIT), Engesserstraße 18, 76128 Karlsruhe, Germany.

${ }^{d}$ Centre for Materials Science, Queensland University of Technology (QUT), 2 George Street, Brisbane, QLD 4000, Australia.

'School of Chemistry and Physics, Queensland University of Technology (QUT), 2 George Street, Brisbane, QLD 4000, Australia.

Email: hatice.mutlu@kit.edu,christopher.barnerkowollik@qut.edu.au

\section{Content}

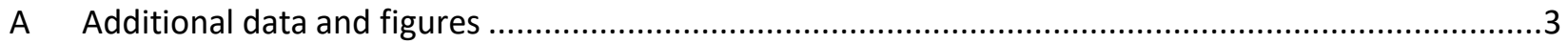

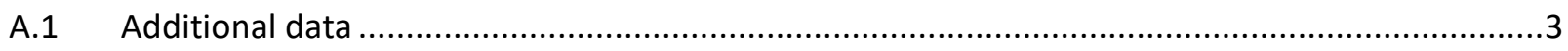

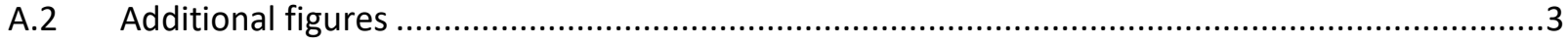

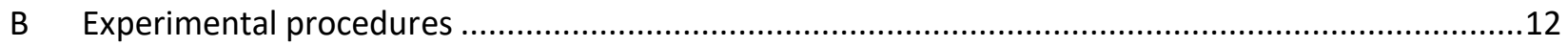

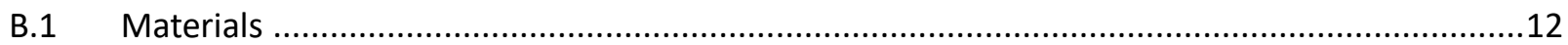

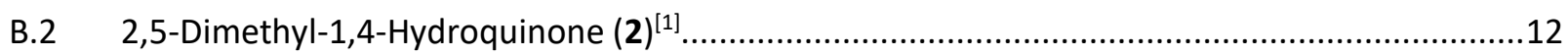

B.3 Bislactone chromanone derivative (3) (4,4,5,9,9,10-hexamethyl-3,4,8,9-tetrahydropyrano[2,3-

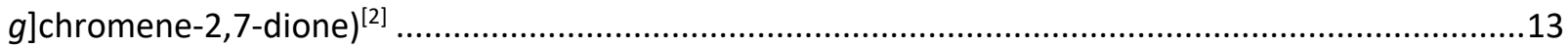

B.4 Bis(3-methylbutanoic acid) derivative (4) (3,3'-(2,5-dimethyl-3,6-dioxocyclohexa-1,4-diene-1,4-

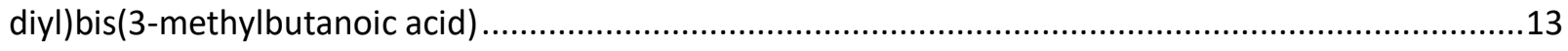

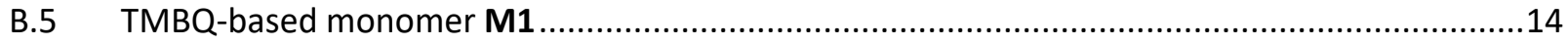

B.6 TMBQ based Acyclic diene metathesis (ADMET) polymer P1 .............................................15

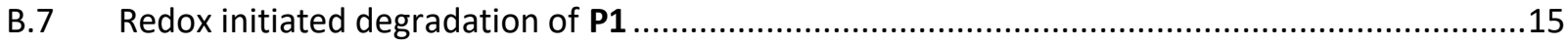

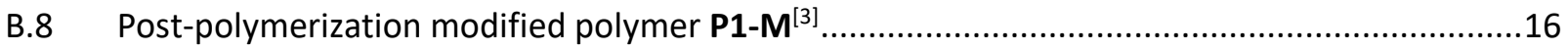

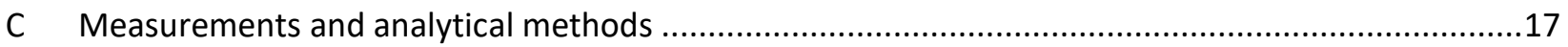

C.1 Nuclear magnetic resonance (NMR) spectroscopy .........................................................17

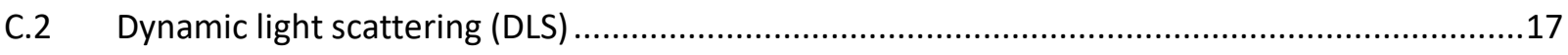


C.3 Ultraviolet-visible (UV/Vis) spectroscopy ......................................................................18

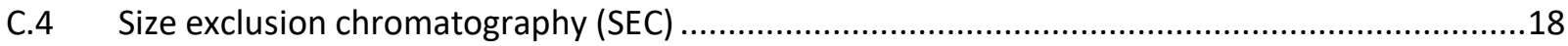

C.5 Gas chromatography - mass spectrometry (GC-MS) measurements .................................18

C.6 Electrospray ionization - mass spectrometry (ESI-MMS) measurements …..........................18

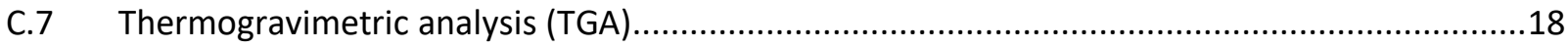

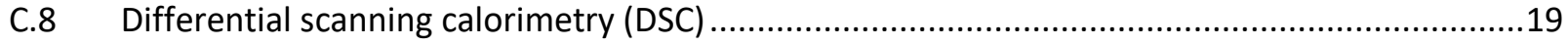

C.9 Attenuated total reflectance Fourier transform infrared (ATR-FTIR) spectroscopy..................19

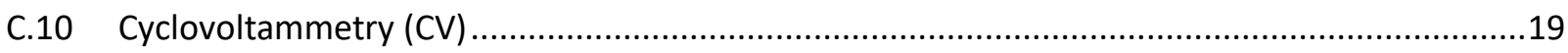

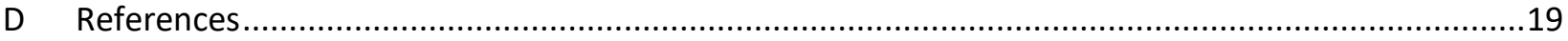




\section{A Additional data and figures}

\section{A.1 Additional data}

Table S1. Experimental screening and condition control for the acyclic metathesis (ADMET) polymerization of monomer M1 in the presence of Hoveyda-Grubbs second generation catalyst (HG-II).

\begin{tabular}{|c|c|c|c|c|c|c|}
\hline & $\begin{array}{c}\text { Solvent } \\
\text { (M) }\end{array}$ & $\begin{array}{c}\text { Catalyst } \\
\text { loading } \\
\text { (mol\%/double } \\
\text { bond) }\end{array}$ & $\begin{array}{c}\text { Reaction } \\
\text { temperature } \\
\left({ }^{\circ} \mathrm{C}\right)\end{array}$ & $\begin{array}{c}\text { Total } \\
\text { reaction } \\
\text { time }(h)\end{array}$ & $\begin{array}{c}\theta\left(M_{\mathrm{w}} / M_{\mathrm{n}}\right) \\
\text { SEC }\end{array}$ & $\begin{array}{c}M_{\mathrm{w}} \\
\left(\mathrm{g} \cdot \mathrm{mol}^{-1}\right) \\
\mathrm{SEC}^{\mathrm{a}}\end{array}$ \\
\hline 1 & bulk & 0.5 & $\begin{array}{l}80^{\circ} \mathrm{C} \text { for } 4 \mathrm{~h} \\
90^{\circ} \mathrm{C} \text { for } 1 \mathrm{~h}\end{array}$ & 5 & 1.5 & 6900 \\
\hline 2 & $\begin{array}{c}\text { o-chlorobenzene } \\
(0.6 \mathrm{M})\end{array}$ & 0.5 & $\begin{array}{l}80^{\circ} \mathrm{C} \text { for } 4 \mathrm{~h} \\
90^{\circ} \mathrm{C} \text { for } 1 \mathrm{~h}\end{array}$ & 5 & 1.8 & 16700 \\
\hline 3 & $\begin{array}{c}\text { o-chlorobenzene } \\
(0.6 \mathrm{M})\end{array}$ & 0.5 & $\begin{array}{l}80^{\circ} \mathrm{C} \text { for } 1 \mathrm{~h} \\
90^{\circ} \mathrm{C} \text { for } 1 \mathrm{~h}\end{array}$ & 2 & 2.3 & 2500 \\
\hline 4 & $\begin{array}{c}\text { o-chlorobenzene } \\
(0.6 \mathrm{M})\end{array}$ & 0.25 & $80^{\circ} \mathrm{C}$ & 5 & 2.0 & 14900 \\
\hline 5 & $\begin{array}{c}\text { Polarclean }^{\circledR} \\
(0.6 \mathrm{M})\end{array}$ & 0.25 & $80^{\circ} \mathrm{C}$ & 5 & 1.5 & 6500 \\
\hline 6 & $\begin{array}{l}\text { Polarclean }^{\circledast} \\
(0.6 \mathrm{M})\end{array}$ & 0.5 & $80^{\circ} \mathrm{C}$ & 5 & 1.7 & 7500 \\
\hline 7 & $\begin{array}{c}\text { Polarclean }^{\circledR} \\
(0.8 \mathrm{M})\end{array}$ & 0.5 & $80^{\circ} \mathrm{C}$ & 5 & 2.1 & 18600 \\
\hline
\end{tabular}

a Determined by SEC using THF as eluent.

\section{A.2 Additional figures}

Quinone

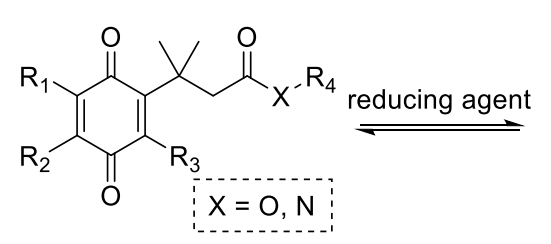

Hydroquinone<smiles>[R]c1c([R])c(O)c(C(C)(C)CC(=O)OCC)c([R3])c1O</smiles>

Tetrahedral intermediate<smiles>[R]c1c([R])c2c(c([R])c1O)C(C)(C)CC(=O)O2</smiles>

Figure S1 Cyclization process of trimethyl-lock propionic acid 1,4-benzoquinones. 


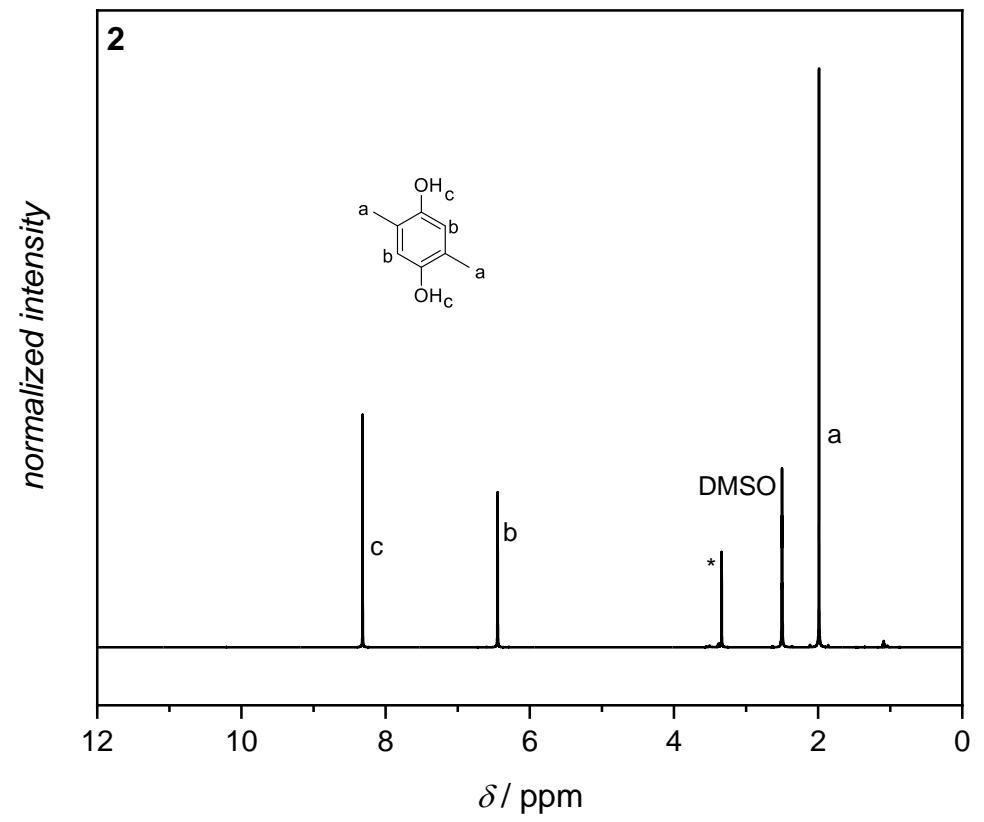

Figure S2 ${ }^{1} \mathrm{H}$ NMR spectra $\left(500 \mathrm{MHz}, \mathrm{DMSO}_{\mathrm{d}}, 298 \mathrm{~K}\right)$ of $\mathbf{2}$. The magnetic resonance marked with an ${ }^{*}$ is assigned to residual water.

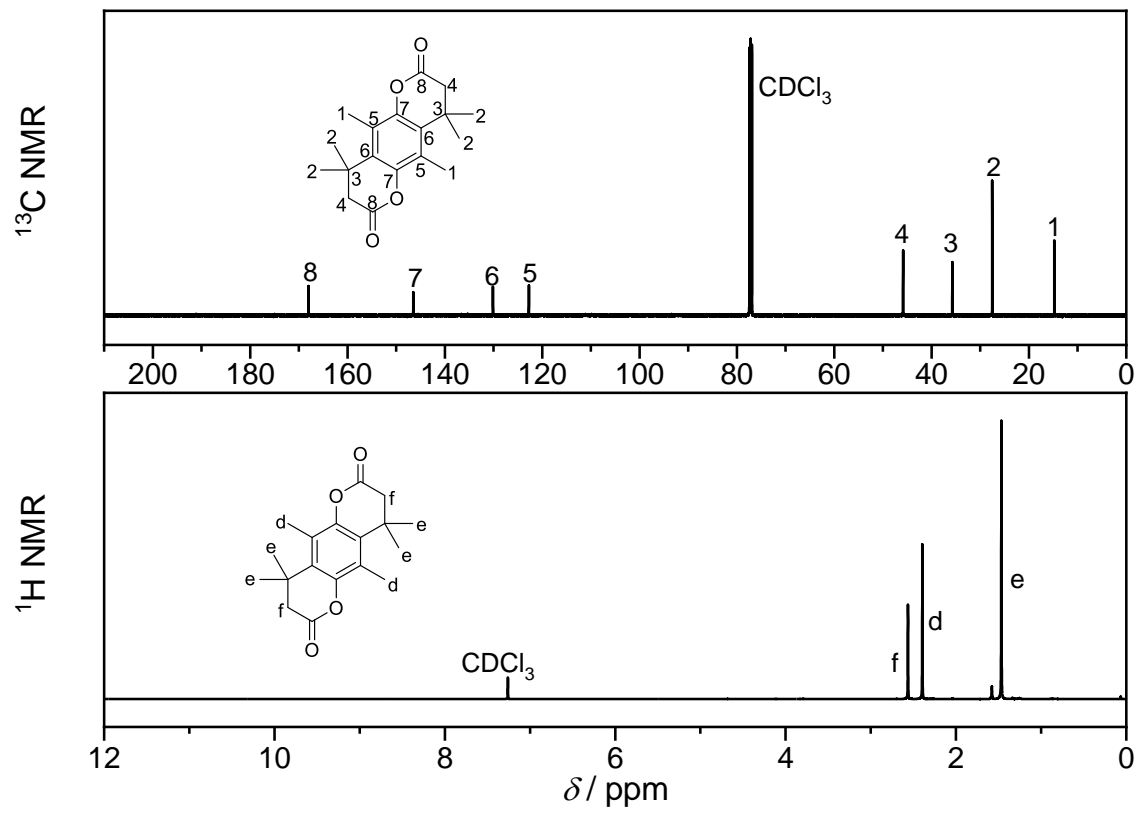

Figure S3 ${ }^{1} \mathrm{H}$ NMR (bottom, $500 \mathrm{MHz}, \mathrm{CDCl}_{3}, 298 \mathrm{~K}$ ) and ${ }^{13} \mathrm{C} \mathrm{NMR}$ (up, $125 \mathrm{MHz}, \mathrm{CDCl}_{3}, 298 \mathrm{~K}$ ) spectra of 3. 


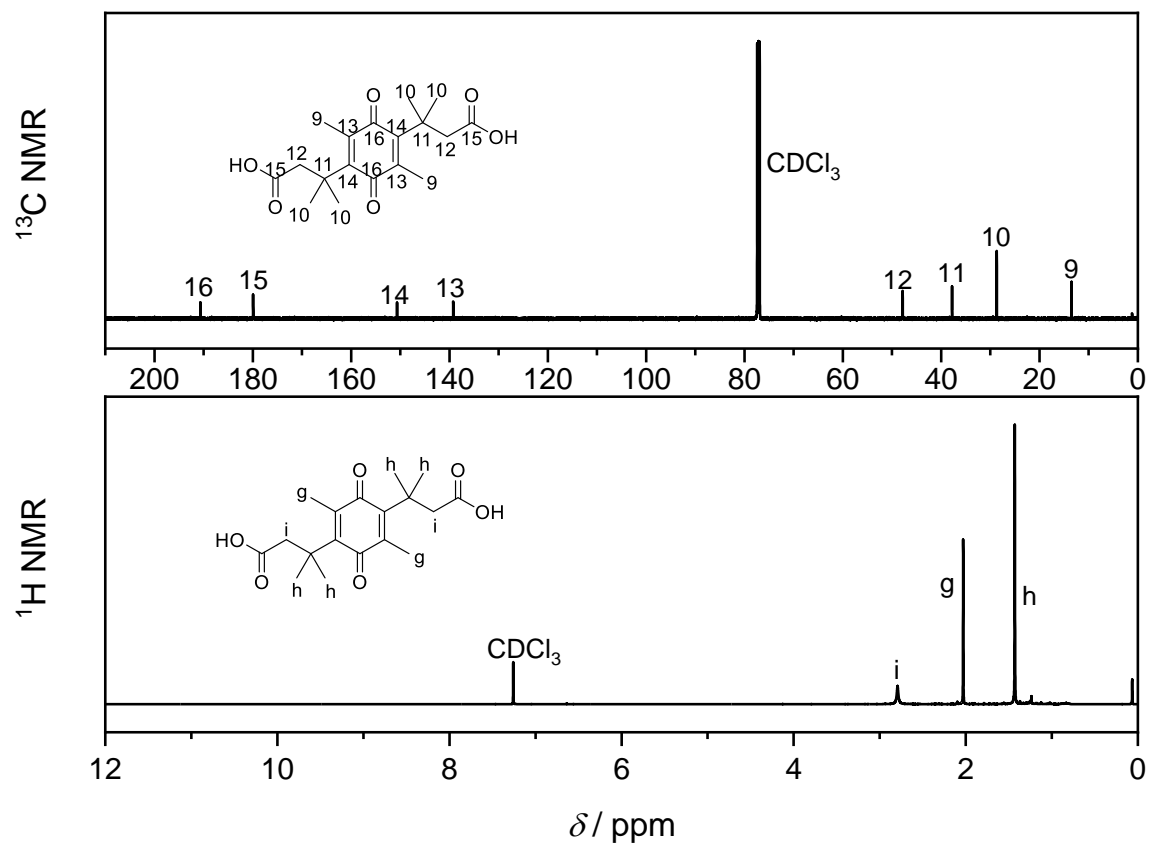

Figure S4 ${ }^{1} \mathrm{H}$ NMR (bottom, $500 \mathrm{MHz}, \mathrm{CDCl}_{3}, 298 \mathrm{~K}$ ) and ${ }^{13} \mathrm{C} \mathrm{NMR}$ (up, $125 \mathrm{MHz}, \mathrm{CDCl}_{3}, 298 \mathrm{~K}$ ) spectra of 4.

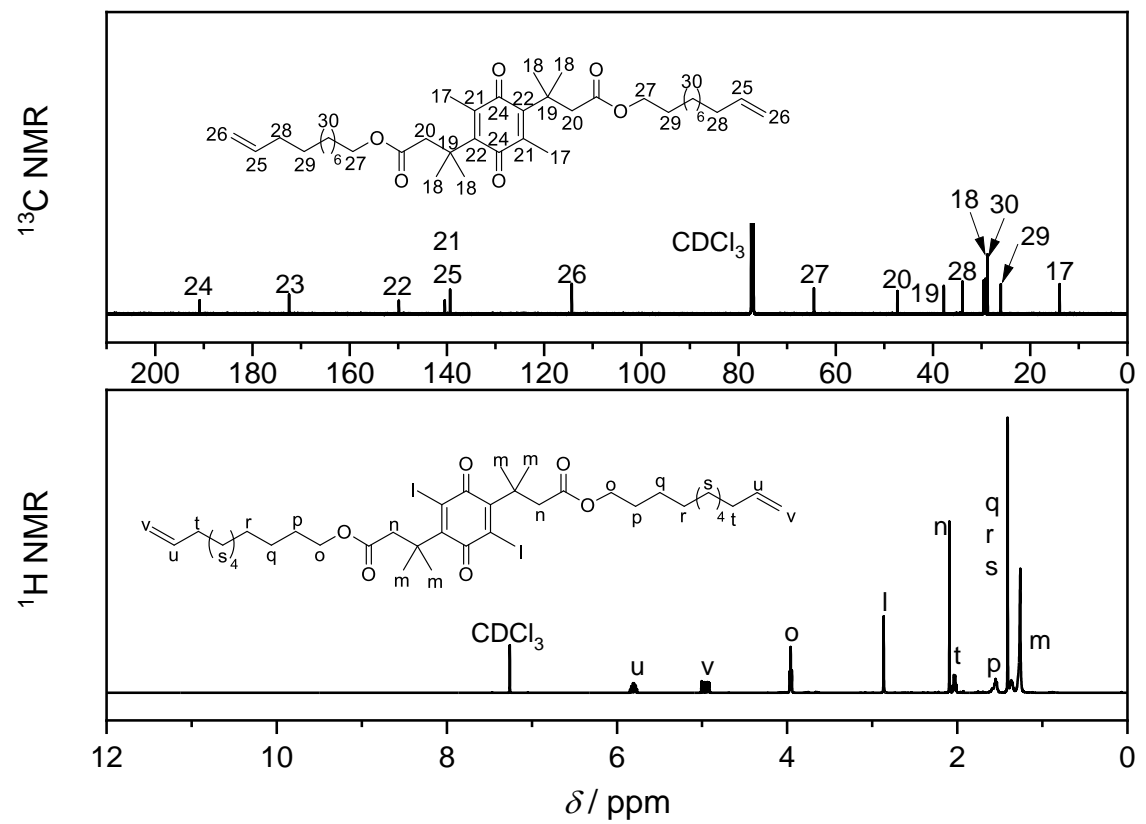

Figure S5 ${ }^{1} \mathrm{H}$ NMR (bottom, $500 \mathrm{MHz}, \mathrm{CDCl}_{3}, 298 \mathrm{~K}$ ) and ${ }^{13} \mathrm{C} \mathrm{NMR}$ (up, $125 \mathrm{MHz}, \mathrm{CDCl}_{3}, 298 \mathrm{~K}$ ) of M1. 


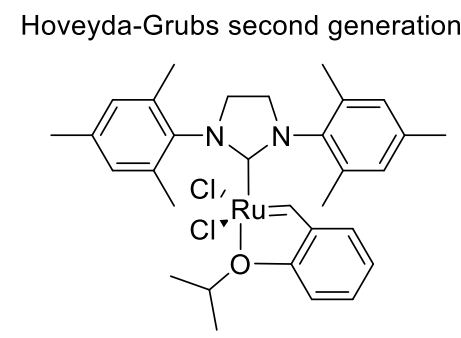

Figure $\mathbf{S 6}$ The chemical structure of the commercially available catalyst for ADMET polymerization, i.e. Hoveyda-Grubbs second generation catalyst, HG-II.

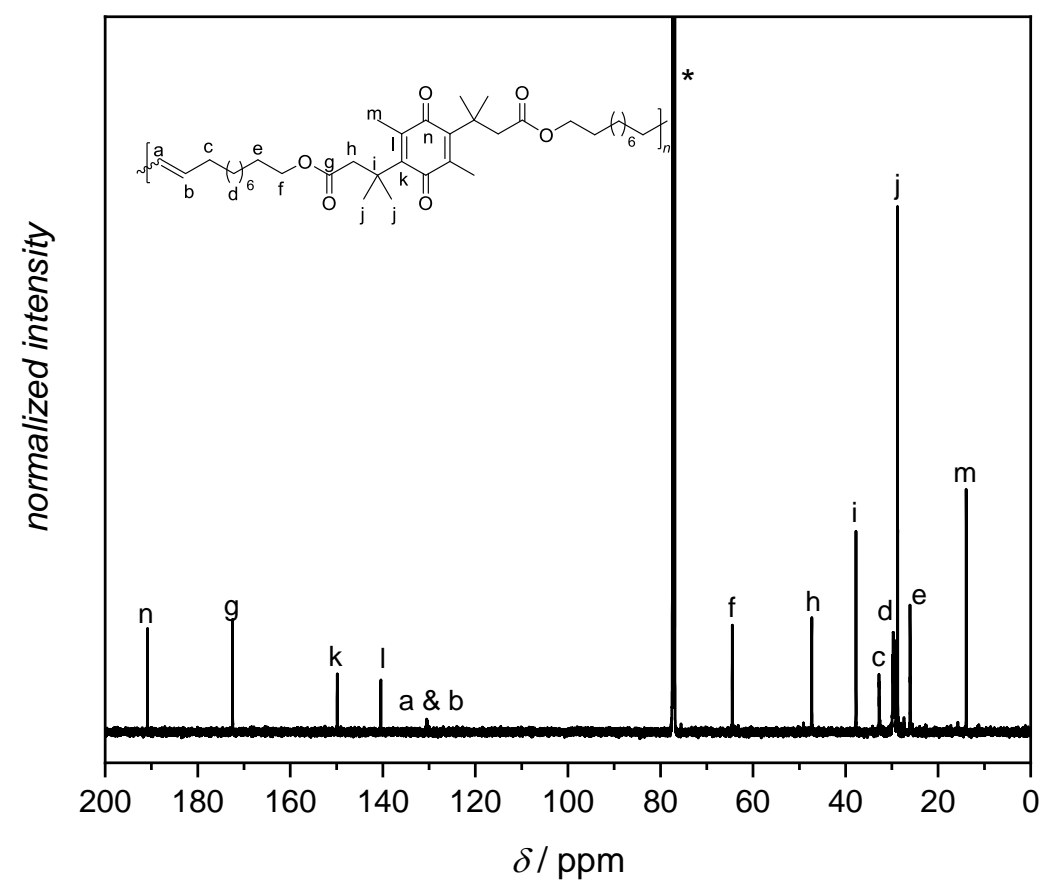

Figure S7 ${ }^{13} \mathrm{C}$ NMR $\left(125 \mathrm{MHz}, \mathrm{CDCl}_{3}, 298 \mathrm{~K}\right)$ spectra of $\mathbf{P} 1$. The magnetic resonance marked with an * is assigned to $\mathrm{CHCl}_{3}$. 


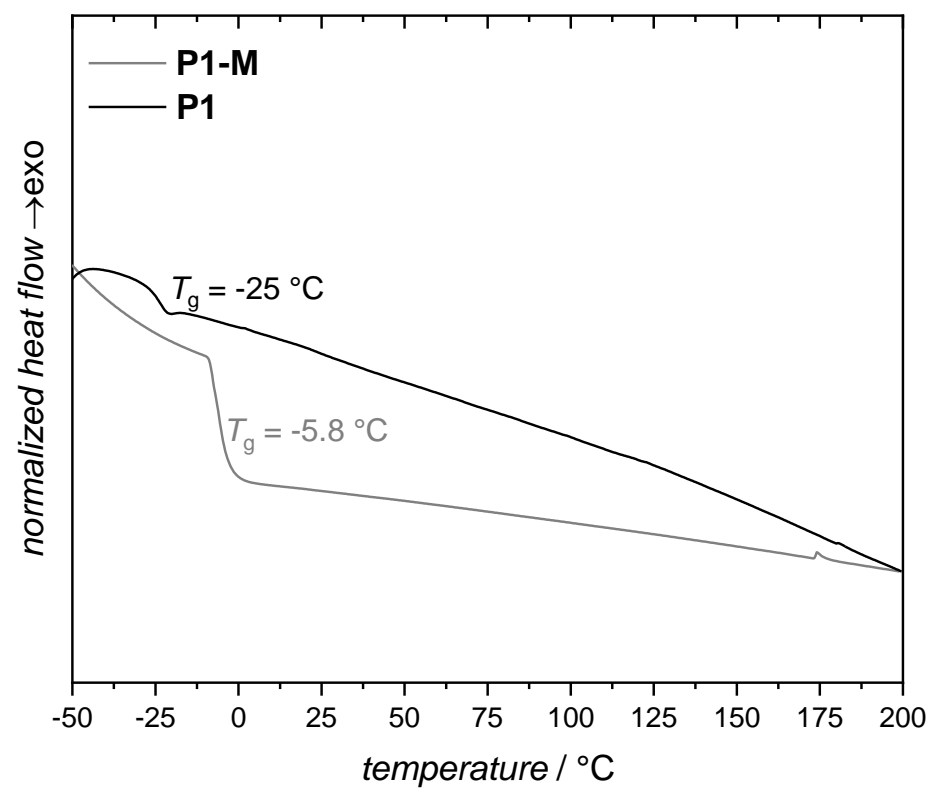

Figure S8 Comparison of the thermal profiles via DSC of redox degradable ADMET polymer P1 (black line) and the postmodified polymer P1-M (grey line).

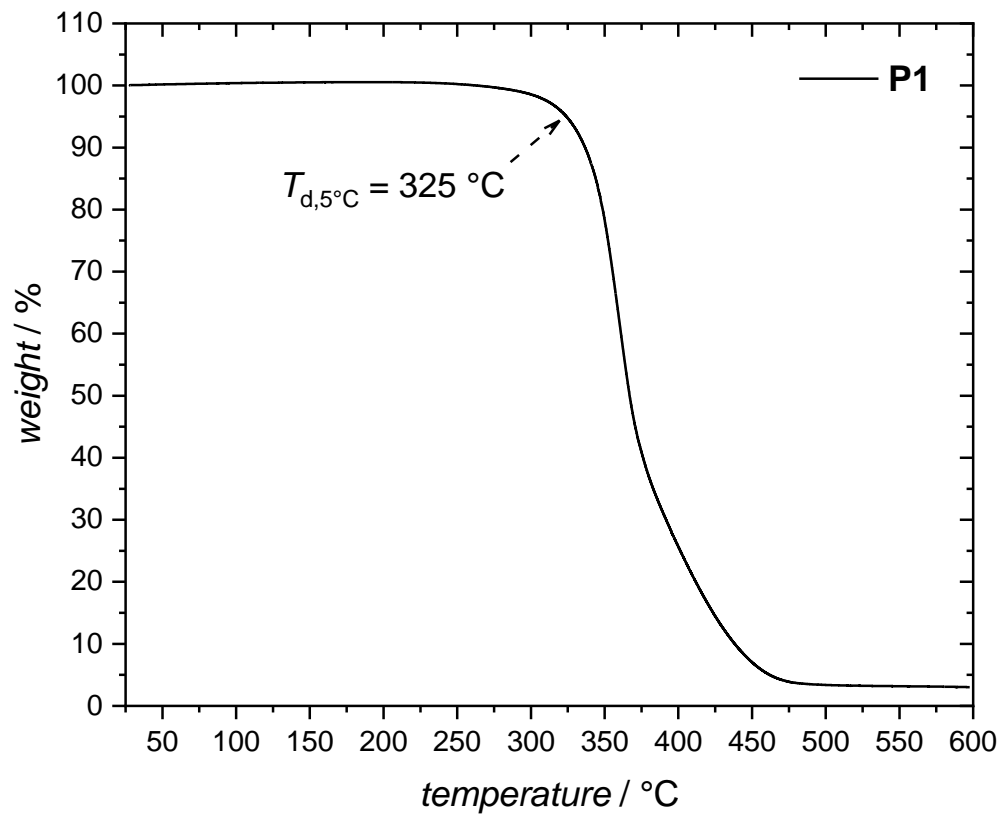

Figure S9 Thermogravimetric (TGA) analysis of $\mathbf{P 1}$ from $25-600^{\circ} \mathrm{C}$ with a heating rate of $5 \mathrm{~K} \cdot \mathrm{min}^{-1}$ under nitrogen flow. 


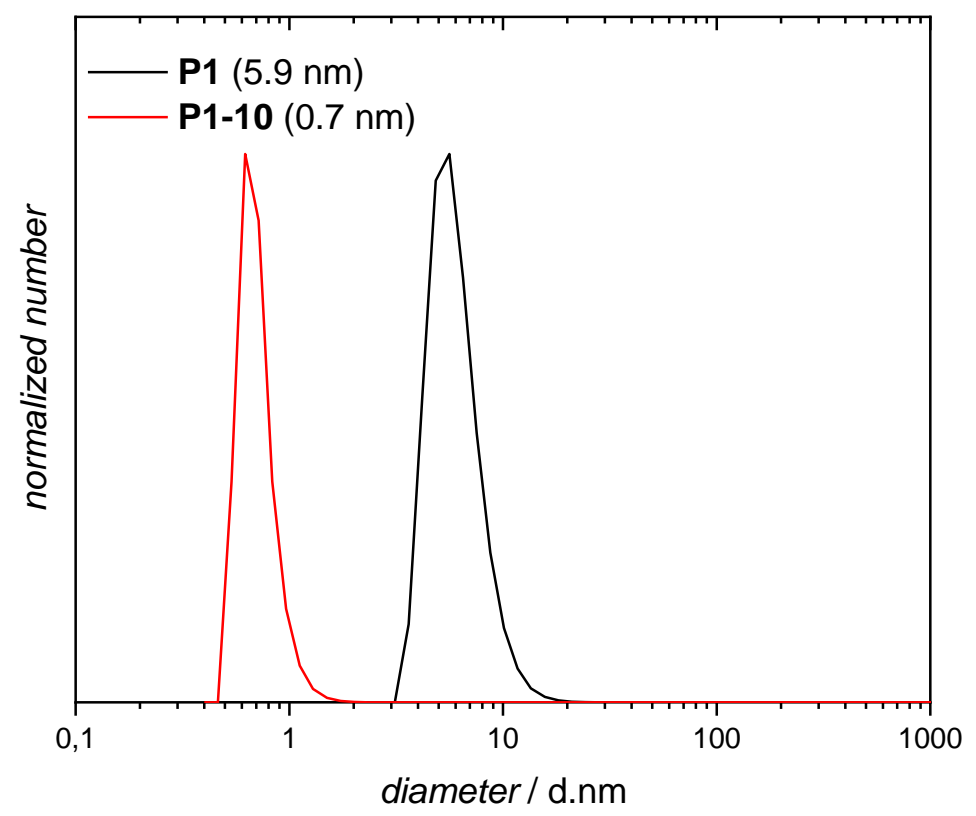

Figure S10 DLS traces of P1 (black line) and P1-10 (red line). All traces were recorded in THF at $20^{\circ} \mathrm{C}$ with $c=1.0 \mathrm{mg} \cdot \mathrm{mL}^{-1}$.

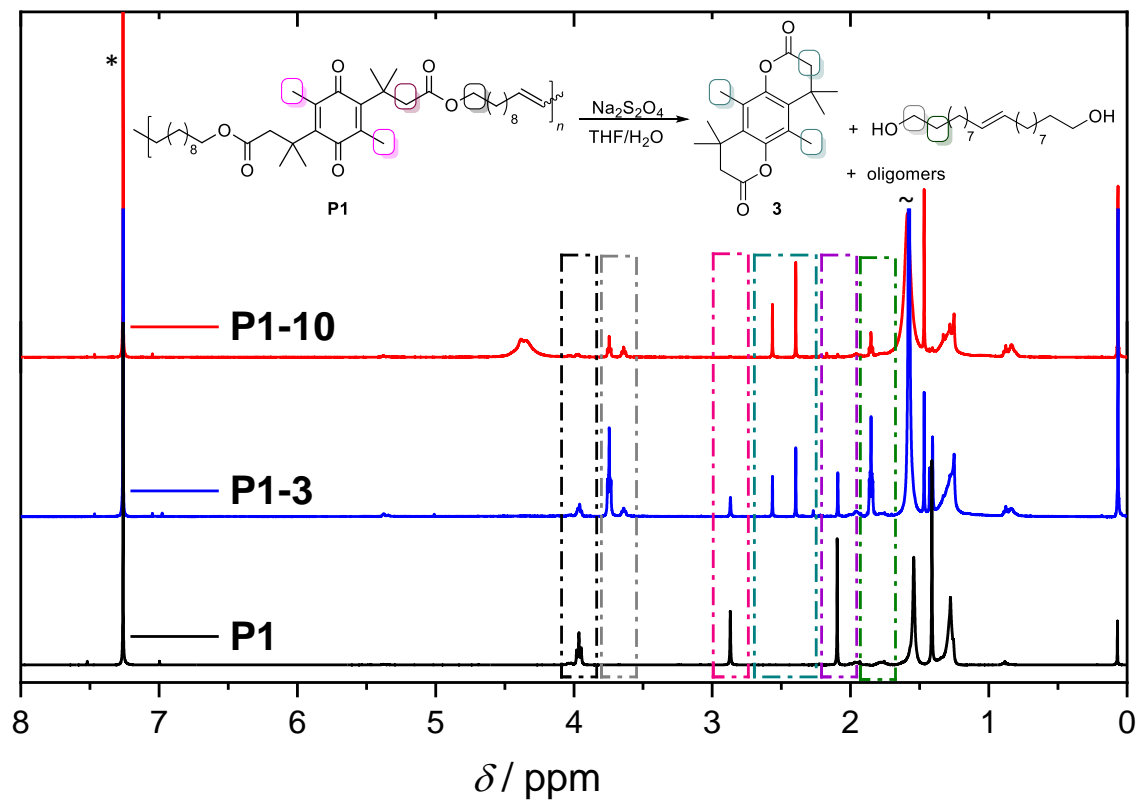

Figure S11 Comparative ${ }^{1} \mathrm{H}$ NMR $\left(500 \mathrm{MHz}, \mathrm{CDCl}_{3}, 298 \mathrm{~K}\right.$ ) spectra of $\mathbf{P 1}$ (black line) in addition to the organic solvent-soluble products of P1-3 (blue line) and P1-10 (red line), respectively. The magnetic resonances marked with * and are assigned to residual $\mathrm{CHCl}_{3}$ and $\mathrm{H}_{2} \mathrm{O}$, respectively. 
(A)

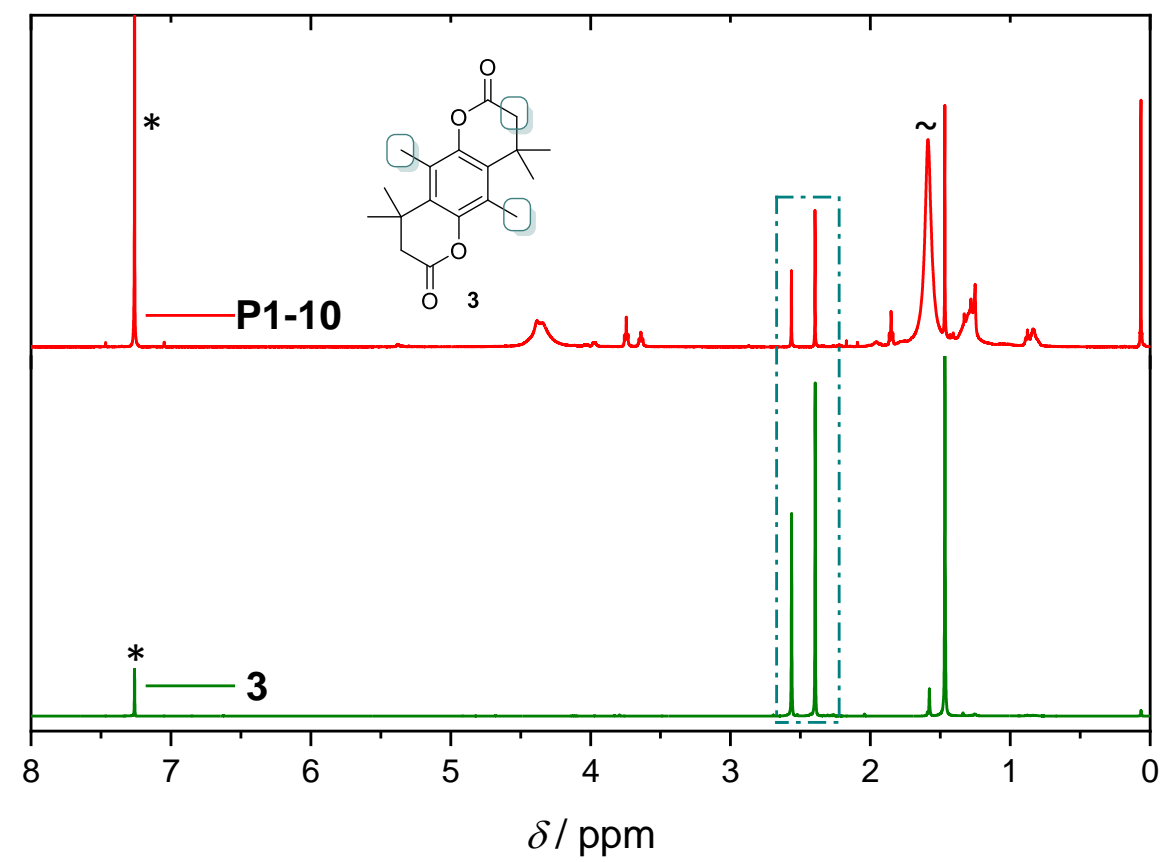

(B)

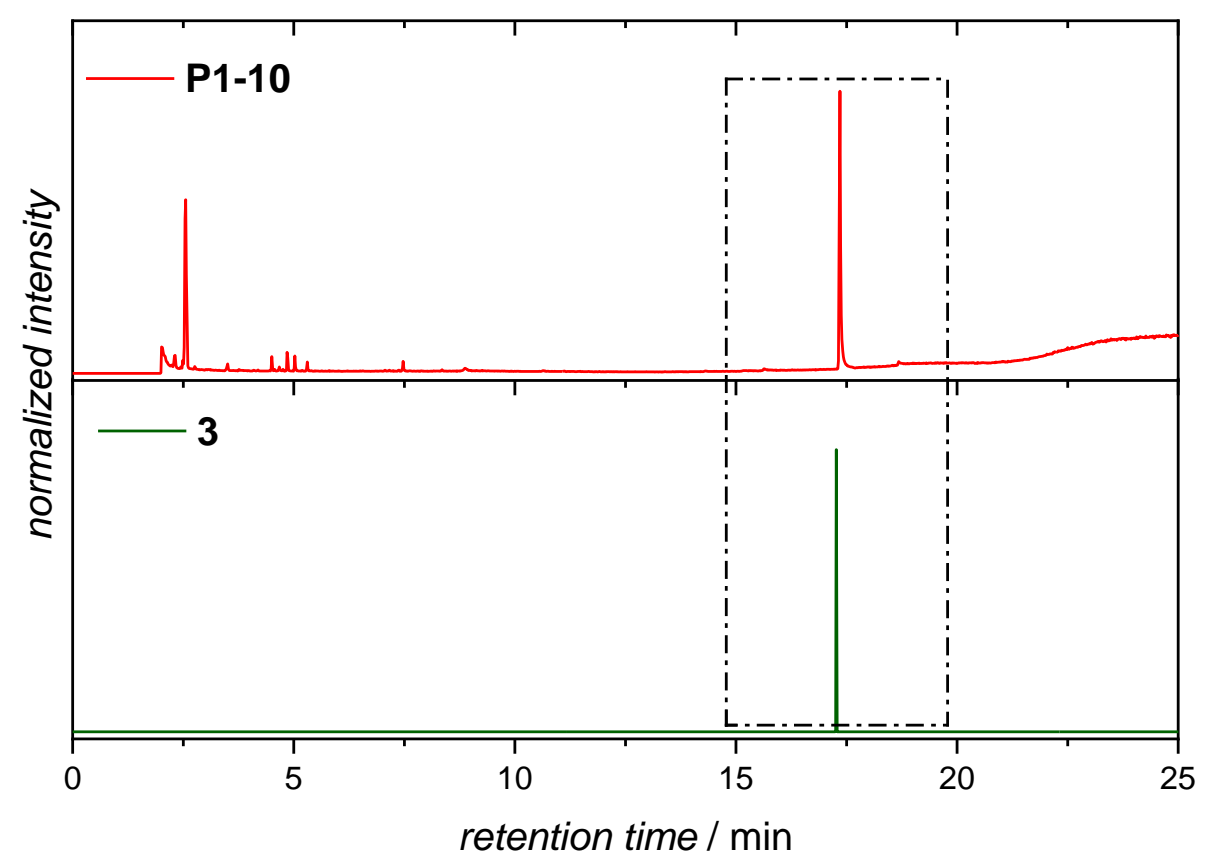

Figure S12 The comparative (A) ${ }^{1} \mathrm{H}$ NMR $\left(500 \mathrm{MHz}, \mathrm{CDCl}_{3}, 298 \mathrm{~K}\right.$ ) and (B) GC-MS traces of the organic solvent-soluble products of P1-10 (red line) and precursor $\mathbf{3}$ (green line). The magnetic resonances marked with * and $\sim$ are assigned to residual $\mathrm{CHCl}_{3}$ and $\mathrm{H}_{2} \mathrm{O}$, respectively. 

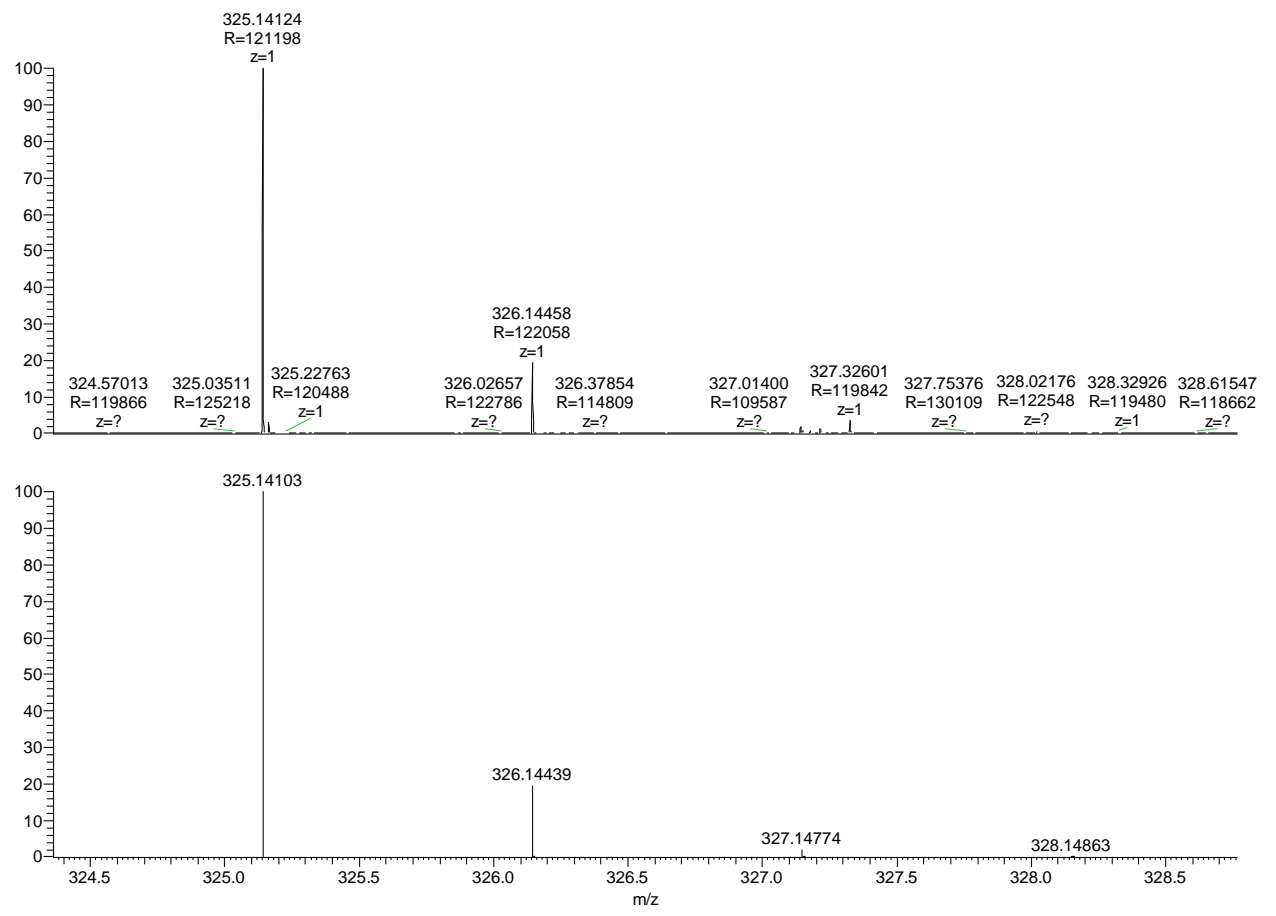

Figure S13 The experimental (up) and theoretical (bottom) high resolution ESI-MS analysis of the organic solvent-soluble degradation fragment of $\mathbf{P 1}$ after reductive treatment for $1 \mathrm{~h}$ in the presence of 10 equivalents of $\mathrm{Na}_{2} \mathrm{~S}_{2} \mathrm{O}_{4}$ to each TMBQ monomer unit (P1-10), evidencing that the organic-soluble degradation mixture was composed of compound 3 with $m / z_{\text {calc }}=325.14,[\mathrm{M}+\mathrm{Na}]^{+}$.

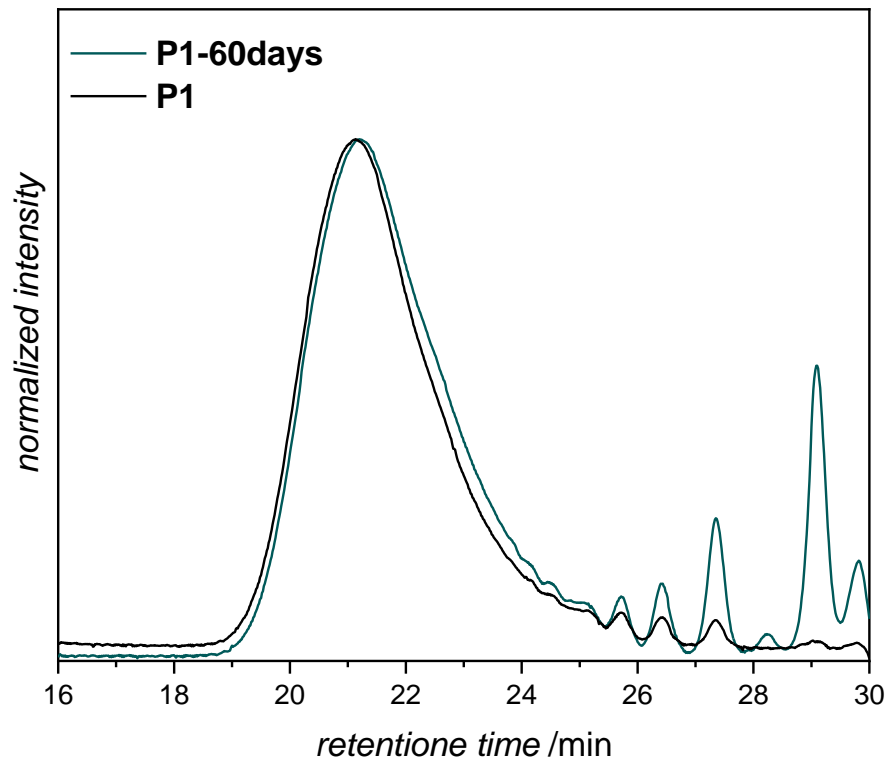

Figure S14 SEC traces of polymer samples P1 and P1-60days, which is obtained after placing P1 in deionised water and stirring the respective solution for 60 days at ambient temperature. 


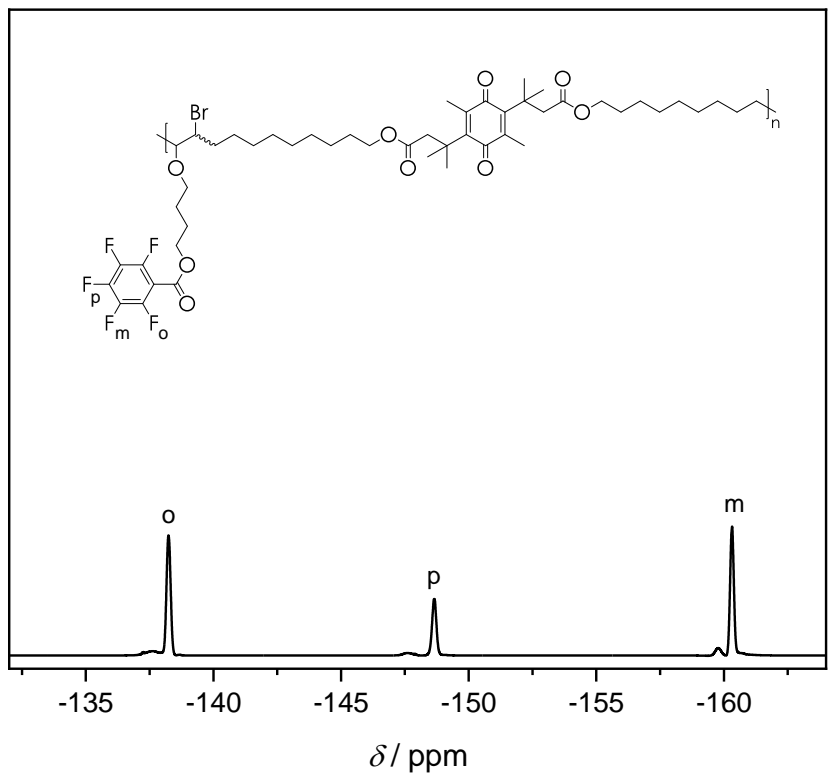

Figure S15 ${ }^{19} \mathrm{~F}$ NMR $\left(471 \mathrm{MHz}, \mathrm{CDCl}_{3}, 298 \mathrm{~K}\right)$ spectrum P1-M which was obtained in an illustrative postmodification example through a catalyst- and metal-free $N$-bromosuccinimide (NBS) initiated electrophilic multicomponent post-polymerization functionalization. The internal olefin functions of P1 were decorated with a bromine and a pentafluorophenyl motif via a chiral alkoxyether bond. 


\section{B Experimental procedures}

\section{B.1 Materials}

Unless otherwise stated, all chemicals were used as received.

Methanesulfonic acid (Sigma Aldrich, 99\%), $\beta, \beta$-dimethylacrylic acid (Sigma Aldrich, 99\%), hexane (VWR, normapur), dichloromethane (DCM, VWR, $99.8 \%$, stabilized with $0.2 \%$ of ethanol), $N$-bromosuccinimide (NBS, Merck, $\geq 99.0 \%$ ), 2,3,4,5,6-pentafluorobenzoic acid (Alfa Aesar, $99 \%$ ), tetrahydrofuran (THF, Acros Organics, 99.5\%, extra dry, over molecular sieves), 10-undecen-1-ol (99\%, Alfa Aesar), 1,1'carbonyldiimidazolefor synthesis (CDI, Merck), sodium dithionite (85\% technical grade, $\mathrm{Na}_{2} \mathrm{~S}_{2} \mathrm{O}_{4}$, Acros Organics), [1,3-bis-(2,4,6-trimethylphenyl)-2-imidazolidinylidene]dichloro(o-isopropoxyphenylmethylene)ruthenium (97\%, Hoveyda-Grubbs second generation catalyst, HG-II, Aldrich),

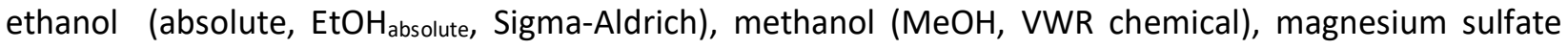
anhydrous (99.5\%, $\mathrm{MgSO}_{4}$, Alfa Aesar), lithium hydroxide ( $\mathrm{LiOH}_{\text {anhydrous, }}$ 98\%, Merck) hydrochloric acid $(32 \%, \mathrm{HCl})$, ethyl acetate (EtOAc, VWR chemical), sodium hydrogen carbonate (Merck, for analysis EMSURE ${ }^{\circledR}$ ACS, $\mathrm{NaHCO}_{3}$ ), silica gel (Sigma Aldrich), Polarclean ${ }^{\circledR}$ (methyl 5-(dimethylamino)-2-methyl-5oxopentanoate, Solvay S. A.).

\section{B.2 2,5-Dimethyl-1,4-Hydroquinone $(2)^{[1]}$}

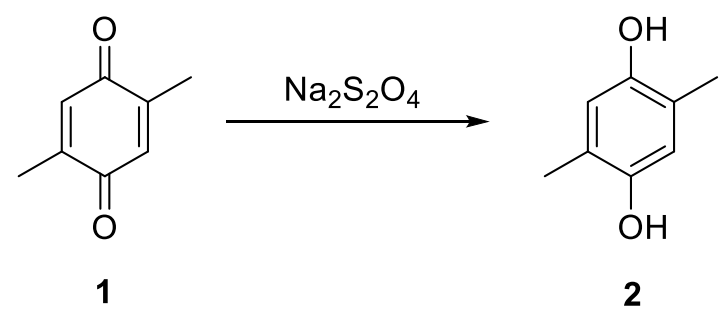

In a $500 \mathrm{~mL}$ beaker, $9.5064 \mathrm{~g}$ of 2,5-dimethyl-1,4-benzoquinone (1) $(69.9 \mathrm{mmol}, 1.00$ eq.) were dissolved in $350 \mathrm{~mL} \mathrm{Et}{ }_{2} \mathrm{O}$, while in a separate beaker $88.7175 \mathrm{~g} \mathrm{Na}_{2} \mathrm{~S}_{2} \mathrm{O}_{4}$ (509.9 mmol, 7.29 eq.) were dissolved in 500 $\mathrm{mL} \mathrm{H}_{2} \mathrm{O}$. Both solutions were slowly transferred into a separating funnel and the yellow-colored organic layer was extracted until the color changed to slightly yellow / almost colorless. The aqueous layer was back extracted with $\mathrm{Et}_{2} \mathrm{O}(2 \times 100 \mathrm{~mL})$ and the combined organic layers were washed with sat. $\mathrm{NaCl}$ solution $\left(2 \times 75 \mathrm{~mL}\right.$ ). Subsequently, the organic layer was dried over $\mathrm{MgSO}_{4}$ and the solvent was removed under reduced pressure, yielding compound 2 as white solid $(8.2568 \mathrm{~g}, 59.8 \mathrm{mmol}, 86 \%)$.

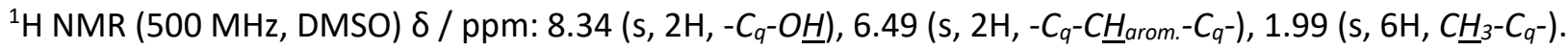




\section{B.3 Bislactone chromanone derivative}

tetrahydropyrano[2,3-g]chromene-2,7-dione $)^{[2]}$

(3)

$(4,4,5,9,9,10-$ hexamethyl-3,4,8,9-<smiles>CC(C)=CC(=O)O[CH+]S(C)(=O)=O</smiles>

3

For the acid catalyzed condensation of 2, $18 \mathrm{~mL}$ methanesulfonic acid were heated to $70^{\circ} \mathrm{C}$ and purged with Ar for $10 \mathrm{~min}$. Subsequently, $2.00 \mathrm{~g}$ of compound 2 (14.49 mmol, $1.00 \mathrm{eq}$.) were dissolved in the heated acid. Slowly, $3.99 \mathrm{~mL} \beta, \beta$-dimethacrylic acid ( $37.75 \mathrm{mmol}, 2.26$ eq.) were added dropwise and the reaction mixture was stirred for $48 \mathrm{~h}$ under Ar atmosphere. After cooling to ambient temperature, the reaction mixture was extracted with EtOAc $(4 \times 100 \mathrm{~mL})$. The combined organic layers were washed with $\mathrm{H}_{2} \mathrm{O}(3 \times 100 \mathrm{~mL})$ and sat $\mathrm{NaHCO}_{3}$ solution $\left(2 \times 100 \mathrm{~mL}\right.$ ) before being dried over $\mathrm{MgSO}_{4}$. The solvent was removed under reduced pressure. Column chromatography (silica gel) with DCM as eluent and subsequent recrystallization in hexane / EtOAc 1:1 yielded the pure bislactone chromanone derivative 3 (1.2565 g, $4.1606 \mathrm{mmol}, 29 \%)$.

${ }^{1} \mathrm{H} \mathrm{NMR}\left(500 \mathrm{MHz}, \mathrm{CDCl}_{3}\right) \delta / \mathrm{ppm}: 2.56\left(\mathrm{~s}, 4 \mathrm{H},-\mathrm{O}-\mathrm{CO}-\underline{\mathrm{C}}_{2}-\right), 2.39\left(\mathrm{~s}, 6 \mathrm{H}, \mathrm{C}_{3}-\mathrm{C}_{q^{-}}-\mathrm{C} q^{-}-\mathrm{O}-\right), 1.47\left(\mathrm{~s}, 12 \mathrm{H},\left(\mathrm{C}_{3}\right)_{2^{-}}\right.$ $\left.\mathrm{C}_{q}-\mathrm{CH}_{2}-\mathrm{CO}-\right)$.

${ }^{13} \mathrm{C} \mathrm{NMR}\left(126 \mathrm{MHz}, \mathrm{CDCl}_{3}\right) \delta / \mathrm{ppm}: 168.18\left(2 \mathrm{C},-\mathrm{O}-\underline{\mathrm{CO}}-\mathrm{CH}_{2^{-}}\right), 146.62\left(2 \mathrm{C},-\mathrm{CO}-\mathrm{O}-\underline{\mathrm{C}}_{q^{-}}\right), 130.31\left(2 \mathrm{C}, \mathrm{CH}_{3}-\mathrm{C}_{q^{-}} \underline{\mathrm{C}}_{q^{-}}\right.$ ), $122.62\left(2 \mathrm{C}, \mathrm{CH}_{3}-\underline{C}_{q^{-}} \mathrm{C}_{q^{-}}\right), 45.94\left(2 \mathrm{C},-\mathrm{O}-\mathrm{CO}-\underline{\mathrm{C}} \mathrm{H}_{2^{-}}\right), 36.12\left(2 \mathrm{C},\left(\mathrm{CH}_{3}\right)_{2}-\underline{\mathrm{C}}_{q^{-}}\right), 27.50\left(4 \mathrm{C},\left(\underline{\mathrm{CH}}_{3}\right)_{2}-\mathrm{C}_{q^{-}}\right), 14.77(2 \mathrm{C}$, $\left.\mathrm{C}_{3}-\mathrm{C}_{q^{-}}\right)$.

B.4 Bis(3-methylbutanoic acid) derivative (4) (3,3'-(2,5-dimethyl-3,6-dioxocyclohexa-1,4-diene1,4-diyl)bis(3-methylbutanoic acid)<smiles>Cc1c2c(c(C)c3c1C(C)(C)CC(=O)O3)C(C)(C)CC(=O)O2</smiles>

3
1. 0.5M LiOH, THF: $\mathrm{H}_{2} \mathrm{O}$

2. $6 \mathrm{M} \mathrm{HCl}$<smiles>CC1=C(C(C)(C)CC(=O)O)C(=O)C(C(C)(C)CC(=O)O)=C(C)C1=O</smiles>

4

In a $500 \mathrm{~mL}$ round bottom flask, $1.4074 \mathrm{~g}$ of 3 (4.6603 mmol, 1.00 eq.) were dissolved in $140 \mathrm{~mL}$ THF and subsequently, $140 \mathrm{~mL} 1 \mathrm{M} \mathrm{LiOH}$ were added. The reaction mixture was stirred openly for $2 \mathrm{~h}$, the conversion being monitored via TLC (DCM / EtOH 19:1). Upon full conversion, the reaction mixture was extracted with EtOAc $(3 \times 150 \mathrm{~mL})$ and washed with $\mathrm{H}_{2} \mathrm{O}(200 \mathrm{~mL})$ and sat. $\mathrm{NaCl}$ solution $(150 \mathrm{~mL})$. The organic layer was 
dried over $\mathrm{MgSO}_{4}$ and the solvent was removed under reduced pressure. Compound 4 was obtained as yellow powder (1.4046 g, $4.6204 \mathrm{mmol}, 99 \%$ ).

${ }^{1} \mathrm{H}$ NMR (500 MHz, CDCl 3 ) $\delta$ / ppm: $2.80\left(\mathrm{~s}, 4 \mathrm{H},-\mathrm{C}_{q}-\mathrm{C}_{2}-\mathrm{COOH}\right), 2.04\left(\mathrm{~s}, 6 \mathrm{H},-\mathrm{C}_{q}-\mathrm{C}_{3}\right), 1.43\left(\mathrm{~s}, 12 \mathrm{H},-\mathrm{C}_{q^{-}}\left(\mathrm{C}_{3}\right)_{2}\right)$.

${ }^{13} \mathrm{C}$ NMR $\left(126 \mathrm{MHz}, \mathrm{CDCl}_{3}\right) \delta / \mathrm{ppm}: 190.88$ (2C, $\left.-\mathrm{C}_{q^{-}} \underline{-} \mathrm{CO}^{-} \mathrm{C}_{q^{-}}\right), 180.11\left(2 \mathrm{C},-\mathrm{CH}_{2}-\underline{\mathrm{COOH}}\right), 151.01$ (2C, $-\mathrm{CH}_{2}-\mathrm{C}_{q^{-}}$ $\left.\underline{\mathrm{C}}_{q^{-}}\right), 139.25\left(2 \mathrm{C}, \mathrm{CH}_{3}-\underline{\mathrm{C}}_{q^{-}}\right), 48.12\left(2 \mathrm{C},-\underline{\mathrm{C}} \mathrm{H}_{2}-\mathrm{COOH}\right), 37.99\left(2 \mathrm{C},-\underline{\mathrm{C}}_{q^{-}} \mathrm{CH}_{2}-\mathrm{COOH}\right), 28.78\left(4 \mathrm{C},-\mathrm{C}_{q^{-}}\left(\underline{\mathrm{C}}_{3}\right)_{2}\right), 13.49$ $\left(2 \mathrm{C}, \mathrm{CH}_{3}-\mathrm{C}_{q^{-}}\right)$.

\section{B.5 TMBQ-based monomer M1}

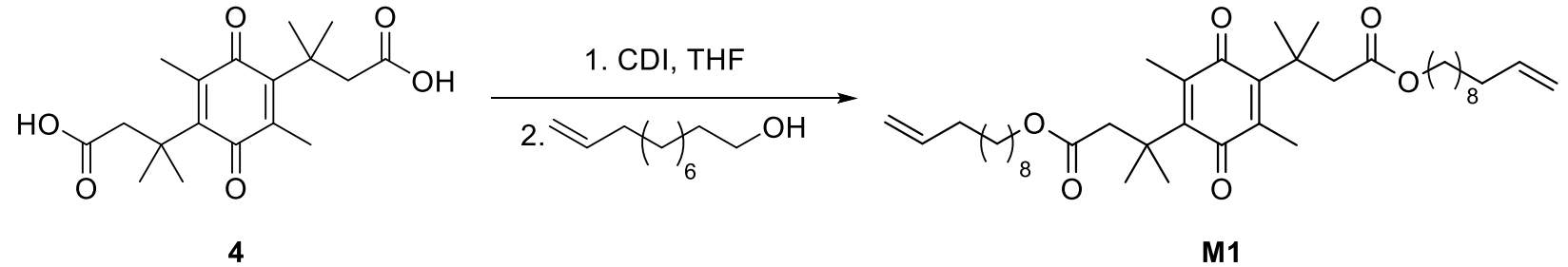

$\mathrm{CDI}(0.7241 \mathrm{~g}, 4.47 \mathrm{mmol}$. 2.1 equiv.) was weighted in $100 \mathrm{~mL}$ round bottom flask and purged with inert gas for $20 \mathrm{~min}$. Afterwards, $10 \mathrm{~mL}$ of THF $_{\text {dry }}$ was added to this flask. In a separate round bottom flask 0.6474 $\mathrm{g}$ ( $2.13 \mathrm{mmol}, 1.0$ eq.) diacid 4 was weighed and the flask was purged with inert gas flow for additional 20 min. Subsequently $6 \mathrm{~mL}$ of dry THF was added to the flask under inert gas flow. The diacid solution was added in a dropwise manner to the solution of CDI in THF (approx. in 15 min time duration). NMR sample was withdrawn after stirring for $1 \mathrm{~h}$ after the addition of the diacid was finalized. To the reaction mixture 10-undecenol ( $0.798 \mathrm{~g}, 2.2$ eq.) dissolved in $3.1 \mathrm{~mL} \mathrm{THF}$ dry $(1.5 \mathrm{M})$ was added in dropwise manner under inert gas flow. Once the addition was finished, $0.1 \mathrm{~mL} \mathrm{Et}_{3} \mathrm{~N}$ (absolute pure) was added. Consequently, the mixture was let to stir for additional 3 days at $50{ }^{\circ} \mathrm{C}$. Subsequently the reaction mixture was cooled to a.t. and the formed clear solution was diluted by addition of $\mathrm{CH}_{2} \mathrm{Cl}_{2}(200 \mathrm{~mL})$, extracted with $\mathrm{H}_{2} \mathrm{O}(200 \mathrm{~mL} \times 3)$. The collected organic phase was dried over $\mathrm{MgSO}_{4}$ and filtered. The filtrate was concentrated on a rotary evaporator and the crude product was dissolved in hexane and passed through short pad of silica to remove the excess of the unreacted alcohol. The final product M1 was isolated as yellow viscous oil in overall yield of $77 \%$.

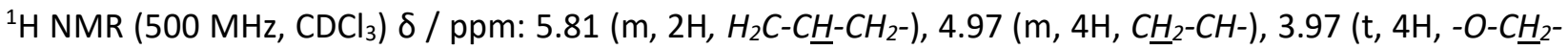
$\left.\left.\mathrm{CH}_{2}\right)^{-}\right), 2.88\left(\mathrm{~s}, 6 \mathrm{H}, \mathrm{CH}_{3}-\mathrm{C}_{q^{-}}\right), 2.11\left(\mathrm{~m}, 8 \mathrm{H},-\mathrm{CO}-\mathrm{CH}_{2}-\mathrm{C}_{q^{-}}, \mathrm{CH}_{2}-\mathrm{CH}-\mathrm{C}_{2} 2^{-}\right), 1.53\left(\mathrm{t}, 4 \mathrm{H},-\mathrm{O}-\mathrm{CH}_{2}-\underline{C}_{2^{-}}\right), 1.41(\mathrm{~m}, 24 \mathrm{H}$, $\left.-\mathrm{CH}-\left(\mathrm{CH}_{2}\right)_{6}-\mathrm{CH}_{2}-\right), 1.25\left(\mathrm{~m}, 12 \mathrm{H},-\mathrm{C}_{q^{-}}\left(\mathrm{C}_{3}\right)_{2}\right)$.

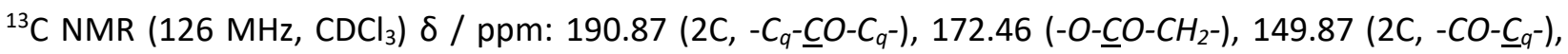

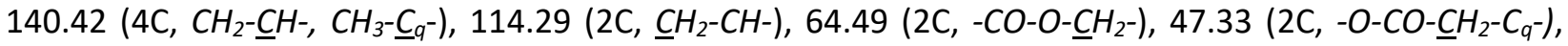

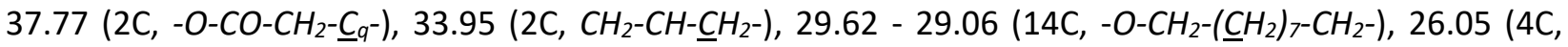
$\left.\left(\mathrm{CH}_{3}\right)_{2} \mathrm{C}_{q^{-}}\right), 13.93\left(2 \mathrm{C}, \underline{\mathrm{CH}}_{3}-\mathrm{C}_{q^{-}}\right)$. 


\section{B.6 TMBQ based Acyclic diene metathesis (ADMET) polymer P1}<smiles>C=CCC(C)OC(=O)CC(C)(C)C1=C(C)C(=O)C(C(C)(C)CC(=O)OCCC=CC)=C(C)C1=O</smiles>

$157 \mathrm{mg}(0.245 \mathrm{mmol})$ monomer M1 was dissolved in $0.8 \mathrm{M}$ polarclean (purified via distillation, $300 \mu \mathrm{L}$ ). To this $1.5 \mathrm{mg} \mathrm{HG}$-II $(2.45 \mu \mathrm{mol}, 1.0 \mathrm{~mol} \%$ /molecule, i.e $0.5 \mathrm{~mol} \% /$ double bonds) was added under inert atmosphere at ambient temperature, subsequently, the reaction was started at $80^{\circ} \mathrm{C}$ under $100 \mathrm{mbar}$ pressure with $500 \mathrm{rpm}$ rotating rate. The first $4 \mathrm{~h} 30 \mathrm{~min}$ of the reaction the pressure was kept at $100 \mathrm{mbar}$, and subsequently the next $30 \mathrm{~min}$ the pressure was adjusted to $50 \mathrm{mbar}$. After total reaction time of $5 \mathrm{~h}$, the reaction mixture was diluted with $5 \mathrm{~mL}$ THF and quenched with addition of ethyl vinyl ether. The polymer was obtained via precipitation in ice-cold $\mathrm{MeOH}$ as a highly viscous yellow colored material.

\section{B.7 Redox initiated degradation of P1}

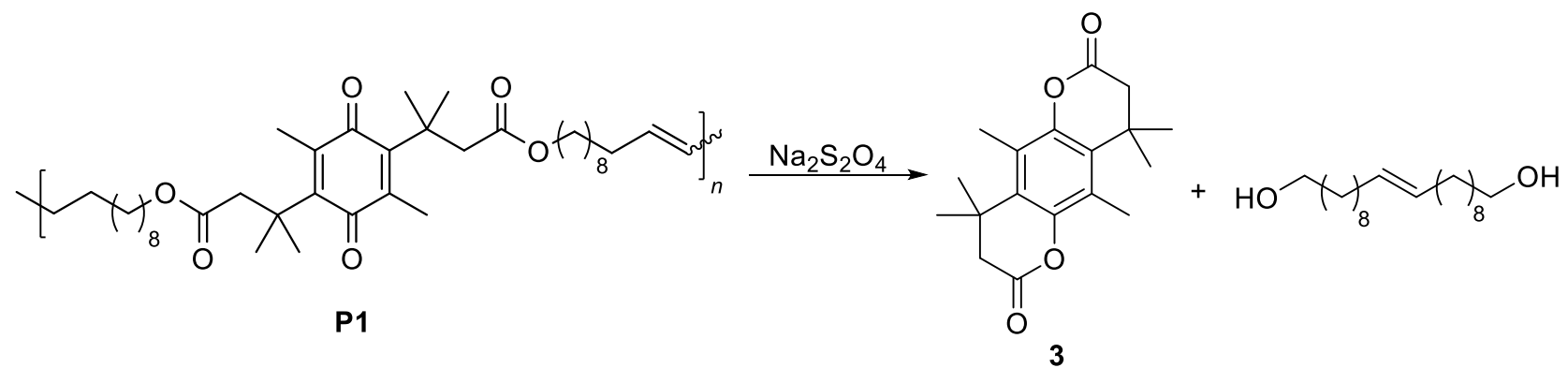

$5 \mathrm{mg}$ (18 $600 \mathrm{~g} \cdot \mathrm{mol}, 0.27 \mu \mathrm{mol}, 29$ repeating units) of polymer was dissolved in $0.5 \mathrm{~mL}$ THF. Subsequently, two different equivalents (e.g. 3 and 10) of $\mathrm{Na}_{2} \mathrm{~S}_{2} \mathrm{O}_{4}$ relative to each TMBQ monomer unit within the P1 $(5.0 \mathrm{mg}$ ) dissolved in distilled water were added under inert gas flow. Each reaction was stopped after $1 \mathrm{~h}$, and accordingly, the reaction mixture was concentrated by the removal of the solvents under reduced pressure. The concentrated mixture was extracted with DCM to separate the organic solvent-soluble products. The organic layer was dried over $\mathrm{MgSO}_{4}$ and the solvent was removed under reduced pressure. The isolated crude product was further analyzed without any purification. 


\section{B.8 Post-polymerization modified polymer P1-M $\mathrm{M}^{[3]}$}<smiles></smiles>

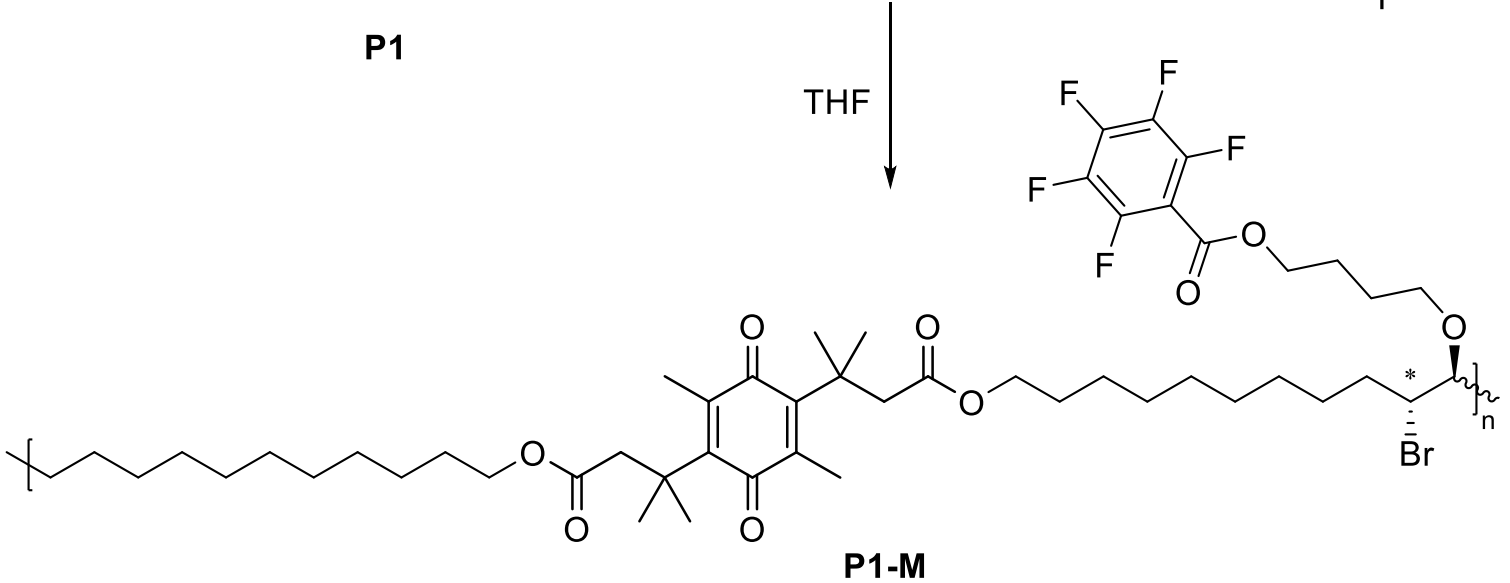

Under anhydrous conditions, $50 \mathrm{mg}$ P1 $\left(M_{\mathrm{n}, \mathrm{SEC}}=18600 \mathrm{~g} \cdot \mathrm{mol}^{-1}, 0.27 \mu \mathrm{mol}, 29\right.$ repeating units of the double bond, 1.00 eq.) and $1.7 \mathrm{mg}$ pentafluorobenzoic acid ( $0.008 \mathrm{mmol}, 1.00$ eq. with respect to the double bonds of the polymer backbone) were dissolved in $5 \mathrm{~mL}$ of dry THF. The reaction mixture was cooled to $0^{\circ} \mathrm{C}$ and $8.54 \mathrm{mg} \mathrm{NBS}(0.048 \mathrm{mmol}, 6.00$ eq. with respect to the double bonds of the polymer backbone) were added. After stirring for $1 \mathrm{~h}$ at $0^{\circ} \mathrm{C}$, the reaction mixture was stirred for further $22 \mathrm{~h}$ at ambient temperature. The residue was filtered off and the solution was concentrated under reduced pressure. Subsequently, the isolated polymer was precipitated into ice cold $\mathrm{MeOH}$. 


\section{Measurements and analytical methods}

\section{C.1 Nuclear magnetic resonance (NMR) spectroscopy}

The NMR spectra were recorded on Bruker Avance $500 \mathrm{MHz}$. Spectra were referenced on residual solvent signal according to Nudelman et al ${ }^{[4]}: 7.26 \mathrm{ppm}$ for $\mathrm{CDCl}_{3}, 2.50 \mathrm{ppm}$ for DMSO-d6. The deuterated solvents were purchased from Euriso-TOP and used without further purification. In order to calculate the degree of polymerization $(D P)$ and the number average molecular weight $\left(M_{n}\right)$ of the ADMET polymers, we took advantage of the ratio of the proton resonances in the ${ }^{1} \mathrm{H}$ NMR associated with the end groups $\left(\boldsymbol{E}_{1}\right.$ and $\left.\boldsymbol{E}_{2}\right)$ compared to the proton resonances of the methylene units $-\mathrm{C}(\mathrm{O}) \mathrm{O}-\mathrm{CH}_{2}-\left(\mathrm{CH}_{2}\right)_{7}$ - of the polymer chain in the ${ }^{1} \mathrm{H}$ NMR spectra shown below. Two types of end groups were detected in the final ADMET polymer P1 as a result of the olefin isomerization of the terminal double bonds:

$E_{1}$ : $\mathrm{CH}_{3}$ - end-group signals at $1.60 \mathrm{ppm}\left(-\mathrm{CH}_{2}=\mathrm{CH}-\mathrm{CH}_{3}\right)$,

$E_{2}: \mathrm{CH}_{3}$ - end-group at $0.88 \mathrm{ppm}\left(-\mathrm{CH}_{2}=\mathrm{CH}-\mathrm{CH}_{2}-\mathrm{CH}_{3}\right)$,

Thus, the degree of polymerization ( $n, D P$ ) was calculated using the integrals of the proton resonances of each end group: $\mathbf{A}$ and $\mathbf{B}$ are respectively the integral values of the resonances associated with end groups $E_{1}$ and $E_{2}$. In addition, $\mathbf{P}$ is the integral value associated with the proton resonances of the methylene units $-\mathrm{C}(\mathrm{O}) \mathrm{O}-\mathrm{CH}_{2}-\left(\mathrm{CH}_{2}\right)_{7}$ - of the polymer chain in the ${ }^{1} \mathrm{H}$ NMR spectra:

$$
\mathrm{n}=D P=(3 \cdot P) /[(A+B) \cdot 2] \quad \text { Formula } 1
$$

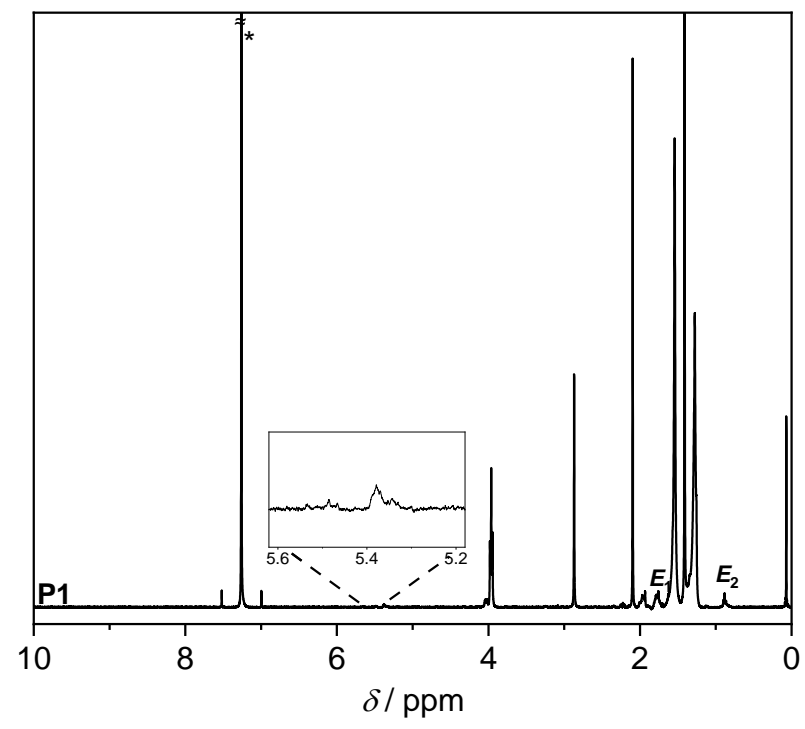

Figure $\mathbf{S 1 6}{ }^{1} \mathrm{H}$ NMR $\left(500 \mathrm{MHz}, \mathrm{CDCl}_{3}, 298 \mathrm{~K}\right)$ spectrum of P1

\section{C.2 Dynamic light scattering (DLS)}

The apparent hydrodynamic diameters $\left(D_{\mathrm{h}, \text { app }}\right)$ were determined at $20{ }^{\circ} \mathrm{C}$ by means of a dynamic light scattering (DLS) analysis using a Zetasizer Nano ZS light scattering apparatus (Malvern Instruments, UK) 
equipped with He-Ne laser (at a wavelength of $633 \mathrm{~nm}, 4 \mathrm{~mW}$ ). The Nano ZS instrument incorporates a non-invasive backscattering (NIBS) optic with a detection angle of $173^{\circ}$. The polymer solutions were prepared in THF ( $\left.c=1 \mathrm{mg} \mathrm{mL}^{-1}\right)$ and were subsequently filtered into disposable micro cuvettes. The prepared samples were stabilized prior to DLS analysis at an ambient temperature. All values of the apparent hydrodynamic diameter for each polymer mixture were averaged over three measurements (14 runs/measurement), and were automatically provided by the instrument using a cumulative analysis.

\section{C.3 Ultraviolet-visible (UV/Vis) spectroscopy}

The absorbance spectra were recorded on a Cary 100 UV-Visible Spectrometer (Agilent Technologies, USA) possessing a tungsten halogen light source (190 to $900 \mathrm{~nm}$, accuracy +/- $2 \mathrm{~nm}$ ) and a R928 PMT detector. For the measurement, the $\mathbf{3}, \mathbf{M} \mathbf{1}, \mathbf{P 1}$, degradation mixtures $\mathbf{P 1 - 3}$ and $\mathbf{P 1 - 1 0}$ were dissolved in THF $(c=$ $4.0^{*} 10^{-6} \mathrm{mmol} \cdot \mathrm{mL}^{-1}$ ) in quartz cuvette, and the samples were analyzed in the range from 250 to $800 \mathrm{~nm}$. The samples were baseline corrected with respect to the pure solvent.

\section{C.4 Size exclusion chromatography (SEC)}

The apparent number average molar mass $\left(M_{n}\right)$ and the molar mass distribution [ $\boxminus$ (dispersity index) = $M_{\mathrm{w}} / M_{\mathrm{n}}$ ] values of the polymers were determined using a size exclusion chromatography (SEC) system equipped with Shimadzu LC20AD pump, Wyatt Optilab rEX refractive index detector and four PLgel $5 \mu$ Mixed-C columns. The characterization was performed at $30^{\circ} \mathrm{C}$ in THF with a flow rate of $1 \mathrm{~mL}^{\cdot} \mathrm{min}^{-1}$. The molecular weight calibration was based on sixteen narrow molecular weight linear polystyrene standards from Polymer Laboratories.

\section{C.5 Gas chromatography - mass spectrometry (GC-MS) measurements}

GC-MS (EI) chromatograms were recorded using a Varian 431 GC instrument with a capillary column FactorFourTM VF-5 ms $(30 \mathrm{~m} \times 0.25 \mathrm{~mm} \times 0.25 \mu \mathrm{m})$ and a Varian 210 ion trap mass detector. Scans were performed from 40 to $650 \mathrm{~m} / \mathrm{z}$ at rate of 1.0 scans $\times \mathrm{s}^{-1}$. The oven temperature program was: initial temperature $95^{\circ} \mathrm{C}$, hold for $1 \mathrm{~min}$, ramp at $15^{\circ} \mathrm{C} \cdot \mathrm{min}^{-1}$ to $200{ }^{\circ} \mathrm{C}$, hold for $2 \mathrm{~min}$, ramp at $15{ }^{\circ} \mathrm{C} \cdot \mathrm{min}^{-1}$ to $325{ }^{\circ} \mathrm{C}$, hold for $5 \mathrm{~min}$. The injector transfer line temperature was set to $250{ }^{\circ} \mathrm{C}$. Measurements were performed in split-split mode (split ratio $50: 1$ ) using helium as the carrier gas (flow rate $1.0 \mathrm{~mL} \cdot \mathrm{min}^{-1}$ ).

\section{C.6 Electrospray ionization - mass spectrometry (ESI-MMS) measurements}

Mass spectra were recorded on a Q Exactive (Orbitrap) mass spectrometer (Thermo Fisher Scientific, San Jose, CA, USA) equipped with an HESI II probe. The instrument was calibrated in the $\mathrm{m} / \mathrm{z}$ range 74-1822 using premixed calibration solutions (Thermo Scientific). A constant spray voltage of $4.7 \mathrm{kV}$ and a dimensionless sheath gas of 5 were applied. The capillary temperature and the S-lens RF level were set to $320^{\circ} \mathrm{C}$ and $62.0 \mathrm{~V}$, respectively. The samples were dissolved with a concentration of $0.05 \mathrm{mg} \cdot \mathrm{mL}^{-1}$ in a mixture of THF:MeOH (3:2) containing $100 \mu \mathrm{mol}$ of sodium trifluoroacetate (NaTFA) and infused with a flow of $5 \mu \mathrm{L} \cdot \mathrm{min}^{-1}$.

\section{C.7 Thermogravimetric analysis (TGA)}

For TGA measurements, a Netzsch STA 409C instrument with $\mathrm{Al}_{2} \mathrm{O}_{3}$ as a crucible material and reference sample was used. The samples $(5-10 \mathrm{mg})$ were heated from $25-600^{\circ} \mathrm{C}$ with a heating rate of $5 \mathrm{~K} \mathrm{~min}^{-1}$ under nitrogen flow. 


\section{C.8 Differential scanning calorimetry (DSC)}

DSC 1 STAR $^{\mathrm{e}}$ system (Mettler Toledo) calorimeter with autosampler under a constant nitrogen flow of 10 $\mathrm{mL} \cdot \mathrm{min}^{-1}$ using $100 \mu \mathrm{L}$ aluminum crucible was utilized for DSC analysis. For analysis the following method was employed: the first heating proceeded from $-50^{\circ} \mathrm{C}$ to $200^{\circ} \mathrm{C}$ at a heating rate of $20^{\circ} \mathrm{C} \cdot \mathrm{min}^{-1}$; a cooling step was performed from $200^{\circ} \mathrm{C}$ to $-50^{\circ} \mathrm{C}$ at a heating rate of $20^{\circ} \mathrm{C}$; the second heating run was recorded from $-50^{\circ} \mathrm{C}$ to $200^{\circ} \mathrm{C}$ at a heating rate of $20^{\circ} \mathrm{C} \cdot \mathrm{min}^{-1}$. The melting temperature, $T_{\mathrm{m}}$, is reported as the minimum of the endothermic peak of the second heating scan unless annealing was used as a pretreatment. The glass transition temperature, $T_{\mathrm{g}}$, is reported as the midpoint of the step change of the heat capacity in the second heating scan. Measurements were performed with samples in the range of 5$20 \mathrm{mg}$.

\section{C.9 Attenuated total reflectance Fourier transform infrared (ATR-FTIR) spectroscopy}

The IR measurements were performed on a Bruker Alpha ATR-IR Spectrometer at ambient temperature with a range of 500 to $4000 \mathrm{~cm}^{-1}$.

\section{C.10 Cyclovoltammetry (CV)}

Cyclic voltammetry measurements were performed on a potentiostat system (PGSTAT128N Metrohm Autolab). CVs of $\mathbf{M} 1$ were conducted at a rate of $0.01 \mathrm{~V} \cdot \mathrm{s}^{-1}$ at $22 \pm 2{ }^{\circ} \mathrm{C}$ in DMSO/0.1 M tetrabutylammonium perchlorate $\left(\mathrm{NBu}_{4} \mathrm{ClO}_{4}, \mathrm{TBAP}\right)$ solution with potential sweeps that started at $1.2 \mathrm{~V}$ to -2.2 and back to 1.2 $\mathrm{V}$. CVs of $\mathrm{M} 1$ were conducted at four different rate of $0.01,0.02,0.03$ and $0.05 \mathrm{~V} \cdot \mathrm{s}^{-1}$, respectively at $22 \pm 2$ ${ }^{\circ} \mathrm{C}$ in DMSO/0.1 M TBAP solution with potential sweeps that started at $0.4 \mathrm{~V}$ to -1.2 and back to $0.4 \mathrm{~V}$. CVs of P1 were conducted at a rate of $0.01 \mathrm{~V} \cdot \mathrm{s}^{-1}$ at $22 \pm 2{ }^{\circ} \mathrm{C}$ in DCM/ $0.1 \mathrm{M} \mathrm{TBAP}$ solution with potential sweeps that started at $0.4 \mathrm{~V}$ to -1.4 and back to $0.4 \mathrm{~V}$. General note: A three-electrode cell was used containing a glassy carbon electrode $\left(A=0.07 \mathrm{~cm}^{2}\right)$, a platinum counter electrode, and an $\mathrm{Ag} / \mathrm{AgCl}(3 \mathrm{M} \mathrm{KCl})$ reference electrode $\left(0.210 \mathrm{~V}\right.$ vs. SHE). Positive current peak corresponds to the reduction peak $\left(E_{\mathrm{p}, \mathrm{c}}\right)$ and negative current corresponds to oxidation peak $\left(E_{\mathrm{p}, \mathrm{a}}\right)$.

\section{References}

1 P. K. Hashim, R. Thomas, N. Tamaoki, Chem. Eur. J. 2011, 17, 7304.

2 S. Ciampi, M. James, G. Le Saux, K. Gaus, J. Justin Gooding, Journal of the American Chemical Society 2012, 134, 844.

3 C. M. Geiselhart, J. T. Offenloch, H. Mutlu, C. Barner-Kowollik, ACS Macro Letters 2016, 5, 1146.

4 G. R. Fulmer, A. J. M. Miller, N. H. Sherden, H. E. Gottlieb, A. Nudelman, B. M. Stoltz, J. E. Bercaw, K. I. Goldberg, Organometallics 2010, 29, 2176. 